\title{
PROFESSIONALISM
}

ISSN: 1893-1049

Volume 11, No 3 (2021), e3970

https://doi.org/10.7577/pp. 3970

\section{Professionals and Volunteers: The Importance of Recognising Diversification in the Healthcare Division of Labour}

\section{Mike Saks ${ }^{1} \&$ Marianne van Bochove ${ }^{2}$}

1. University of Suffolk, UK

2. Erasmus School of Health Policy \& Management, Erasmus University Rotterdam, The Netherlands

Contact: Mike Saks, University of Suffolk, UK, $\underline{\text { m.saks@uos.ac.uk }}$

\section{Abstract}

In sociological research on relationships between professionals and volunteers, professionals are often contrasted with volunteers as abstracted, distinct and homogeneous groups. Focusing on healthcare in selected modern societies, and adopting a neo-Weberian and complementary boundary work perspective, this essay argues the landscape is more complex than between paid groups with exclusionary social closure and the unwaged in the market. First, diversification exists within health professions themselves based on social closure, with hierarchies and differential scopes of practice. Second, unpaid volunteers vary in responsibility depending on factors like employment sector and social background, including qualifications and experience. Third, in the paid workforce, there are interstitial non-professionalised health occupations, such as the neglected, lower educated health support workers, forming the largest, most heterogeneous healthcare labour force. Drawing on studies of healthcare, it is argued that recognising the diversification and interplay 
between professionals, volunteers and support workers is vital for enhancing health policy.

\section{Keywords}

Diversification, division of labour, healthcare, professions, volunteers

\section{Introduction}

A burgeoning literature by sociologists and other contributors exists on volunteers in healthcare in modern neo-liberal societies (e.g. Eliasoph, 2011; Hardill \& Baines, 2011; Handy \& Srinivasan, 2004). Much of this compares volunteers with other workers contrasting, amongst others, unpaid volunteers with paid workers (Handy, Mook \& Quarter, 2008) and volunteers with managers (Kreutzer \& Jäger, 2011). Some publications have been more subtle in acknowledging different levels at which professionals and volunteers operate in healthcare (e.g. Hoad, 2002; Merrell, 2000; Overgaard, 2019). However, in work comparing volunteers with healthcare professionals and other highly ranked paid workers, they are often depicted as abstracted, distinct and homogeneous groups. This fails to reflect complexities in the healthcare division of labour - which go beyond differing national cultures that impact on the healthcare workforce (de Bont et al., 2016).

This essay develops a more elaborated account of the comparison and interlinkages of volunteers with professionals in healthcare, illustrated largely but not exclusively by the Anglo-American context and Northern Europe in the modern neo-liberal world. The interrelated elements of the division of labour are examined as a backdrop to future research into the professional-volunteer relationship. The central research question is: What are the characteristics of, and divisions within and between, the various players in the healthcare arena relevant to the interface of professionals and volunteers? This question is explored primarily through a neo-Weberian lens, followed by a brief elaboration of the methods used. The analysis focuses on occupational diversification in healthcare and raises various sub-issues concerning the relationship between professionals and volunteers, including professional boundary creation, the role of support workers, self-help and informal carers. In arguing for the importance of recognising diversification in the healthcare division of labour, the essay finally discusses the implications for future studies of professionals and volunteers, as well as policy and practice.

\section{The relationship between professionals and volunteers: Theory and methods}

For neo-Weberians the key to theoretically understanding the division of labour lies in differential market positions (Saks, 2016). Accordingly, neo-Weberians define professions in terms of exclusionary social closure in the market, drawing on the classic work of Max Weber (Parkin, 1979). Professionals have an advantaged position in an interest-driven, 
competitive marketplace as they typically command greater financial and other privileges based on legal closure. A neo-Weberian market perspective on the relationship between professionals and volunteers also implies differentiating both groups, rather than simply distinguishing paid professional groups and the non-professionalised unwaged. Following neo-Weberian market logic, there are additionally interstitial occupational groups critical to healthcare provision.

This theoretical approach is complemented by a boundary work perspective. Here studies of professional-volunteer relationships highlight that boundary work is not just about interestbased strategic boundary protection in neo-Weberian accounts, but also the shaping of boundaries in occupational interaction (Hoad, 2002; Merrell, 2000; van Bochove, Tonkens, Verplanke \& Roggeveen, 2018). The emphasis on work originates from the interactionist tradition linked to Weber (Saks, 2016) which highlights that boundaries are not just "out there" (Halffman, 2003), but are constantly (re)crafted. Boundary work is often understood as demarcation work, studying the erection and maintenance of boundaries (Fournier, 2000)-as, for instance, through monopolisation, expansion, exclusion and protection (Gieryn, 1995) - but it is also about boundaries being bridged or crossed (Halffman, 2003). This helps to explain why professionals and volunteers (and/or support workers) sometimes emphasise differences, while in other circumstances, they are less relevant.

Methodologically this essay draws on our earlier macro to micro research on healthcare professions and health support workers (e.g. Saks, 2015b; Saks, 2020) and voluntary work and professional-volunteer relationships (e.g. van Bochove \& Oldenhof, 2020; Verhoeven \& van Bochove, 2018). We also undertook a selective literature review of theoretically-based empirical studies known to us through referencing healthcare, based on their rigour and relevance to our research aims (for similar approaches, see Hallett \& Barber, 2014; Nixon \& Crewe, 2004). On this basis, we found that, while contributors on healthcare professions and volunteers in modern societies were attentive to internal diversity, the implications of diversification for the relationships between professionals and volunteers-as well as nonprofessionalised groups of health support workers - were largely unexplored.

Historic literature on volunteers is predominantly survey-based and focused on background characteristics and motives (Wilson, 2012). Although Taylor (2005) argues that 'rigorous qualitative research' on voluntary work is scarce, recent research includes qualitative and ethnographic studies of the volunteer experience-including relationships with clients, other volunteers and paid professional staff. Various studies apply a boundary work perspective to settings from social and long-term care (van Bochove et al., 2018) and palliative care (Claxton-Oldfield, Gibbon \& Schmidt-Chamberlain, 2011) to well women clinics (Merrell, 2000), hospitals (Handy \& Srinivasan, 2004) and patient organisations (Kreutzer \& Jäger, 2011). This has involved unstructured, semi-structured and structured interviews, participant and non-participant observation, and focus groups with varying numbers and types of subjects. 
Neo-Weberian research on professions in the modern healthcare division of labour has focused on high-level policy analysis at the macro level, centred on primary and secondary literature (Saks, 2015b). It has mainly concentrated on doctors (e.g. Chamberlain, 2015; Stevens, 2003), but has sometimes overviewed the historical and contemporary position of other health professions like nursing and midwifery (Borsay \& Hunter, 2012) and allied health workers' relationships with paid health support workers (Nancarrow, 2020). Drawing on these fields, this essay charts the nature and divisions within and between volunteers and professionals in healthcare. The resulting complexity is very apparent in the form taken by healthcare professions, where our analysis begins.

\section{Healthcare professions in the division of labour}

The neo-Weberian concept of exclusionary closure underlines how health professions regulate competitive market conditions in their favour with state support by creating legal monopolies. Consequently, professions with which volunteers deal are able to restrict opportunities in their own interests to a limited group of eligibles, whilst creating legally defined outsiders (Saks, 2012). The definition of a profession varies depending on whether market control is seen as direct or derivative. In the former case, the medical profession in Britain is viewed as having power over service provision through a self-regulating association of equals (Parry \& Parry, 1976). In a more derivative sense, medicine is defined as a profession because of its legitimate organised autonomy over technical judgements and the organisation of work (Freidson, 2001) or because of its power over consumers (Johnson, 2016).

Central to these neo-Weberian definitions is that professions command high income, status and power underwritten by the state, based on prescribed educational credentials (Parkin, 1979). There are national differences, though, in the exercise of their authority. In welfare state-driven Britain, for instance, medicine involves a de facto monopoly whereby those on the register have legal protection of title, while other non-professional healthcare workers can practise under the Common Law. In the more entrepreneurial United States, though, a de jure professional monopoly operates through state-by-state licensure (Saks, 2015b). The power of medicine, though, is fast-changing with, inter alia, rising corporatisation, the New Public Management, expanding state regulation and the emergence of multinational professional service firms (Chamberlain, Dent \& Saks, 2018). Such trends have been moderated by resistance and adaptation in healthcare professions through hybridisation in which professionals act as intermediaries between managers and clients (Noordegraaf, 2016). Moreover, strong patterns of self-regulation in healthcare exist outside the AngloAmerican context in countries like Australia, Canada and Germany (Saks, 2021).

Such patterns necessarily impact on the relationship between professionals and volunteers. So too does differentiation between health professions in terms of social closure, manifested in varying scopes of practice and hierarchical positioning in the professions. 
Further divisions are based on factors like gender and ethnic minority status (Andrews \& Wærness, 2011). Neo-Weberians have viewed less esteemed professions than medicine as experiencing dual closure, encompassing both professional exclusivity and the solidaristic union-style tactics of the working class (Parkin, 1979). This certainly applies to semiprofessions like nurses in Britain who have professional standing, but are lesser paid and lower status than doctors, despite enhanced specialisation (Borsay \& Hunter, 2012). Nonetheless, as Carvalho (2014) relates in the Portuguese case which has applicability elsewhere (Noordegraaf, 2016), nurses have resisted deprofessionalisation through local negotiation with managers and organisational hybridisation.

The professional pecking order is relevant to the dynamic relationship between professionals and volunteers given frequent interest-based conflicts (e.g. King et al., 2019), not least in relation to supporting healthcare personnel (Nancarrow 2020). The impact on volunteers is accentuated by the categorisation by Turner (1995) in which medicine dominates modern healthcare, reinforced by allied and other health professions, labelled subordinate professions. They complement limited professions including occupations with legally protected territory linked to particular body parts or therapeutic methods - like dentistry, optometry, pharmacy and podiatry. Finally, the category of exclusion encompasses marginal non-professionalised practitioners of complementary and alternative medicine-even if chiropractors and osteopaths have now become state licensed professions on both sides of the Atlantic (Saks, 2015a).

\section{The relationship of volunteers to professionals: The impact of diversification}

Professionals are not the only stratified group in the market. Volunteers are as well, which also impacts on their interface with professionals. Wilson (2012), for instance, considers factors influencing factors such as personality traits, education level, life course and gender. However, his review was mainly based on articles centred on social surveys. Greater detail is therefore needed on how unwaged volunteers relate to paid professional staff and other healthcare workers. But if "collaborative working between volunteer and paid workers has been under explored" (Merrell, 2000, p. 93), more recent micro-level and meso-level qualitative studies have focused on interactional boundary work between these groups, including professionals in health and social care (e.g. van Bochove et al., 2018). Much of this literature addresses mutual tasks and/or responsibilities, especially volunteers assisting or replacing paid professionals and asks whether professionals can reciprocally take volunteers' positions in voluntary organisations.

Some studies draw a line between the roles of volunteers and professionals. The study of six patient organisations in different European countries by Kreutzer and Jäger (2011), for example, depicted them as "dual identity associations" - in which volunteer and managerial identities were inherently opposed. Handy and Srinivasan (2004), meanwhile, observed 
from their study of 31 Canadian hospitals that non-market emotional support by volunteers contrasted with market-like interactions of medical professionals with patients. These studies emphasise differences in tasks between volunteers and paid workers in identities, motivations and other qualities. The boundaries between them seem clear and stable as healthcare professionals and managers use a different discourse to volunteers and have different tasks. However, other methodologically well-grounded studies of care settings have shown that the differences between professionals and volunteers are not clear cut, but ambiguous and dynamic (Hardill \& Baines, 2011; Hoad, 2002; Merrell, 2000; Taylor, 2005; van Bochove et al., 2018). Two important reasons for such variations in boundary demarcation and blurring are suggested-differences in types of professional closure and differences among volunteers.

\section{The impact of differences in professional closure}

Cross-national comparisons of professional-volunteer collaboration are scarce, but Overgaard (2015) helpfully compared two hospices in Denmark and Australia. She found that in Australia volunteers took over some tasks of paid staff and received training to minimise risks, while in Denmark there was no overlap with volunteers and paid staff. As the differences were not attributable to care service characteristics or the individuals involved, Overgaard concluded that professional closure was decisive. In the Danish welfare state, care is the responsibility of qualified paid staff and in palliative care nursing professionals maintained a monopoly. In contrast, in Australia, families have primary responsible for caregiving - which explains why nursing professionalisation has been less successful-with volunteer training to minimise risks in taking over selected tasks. More recently, Overgaard (2019) argues that earlier findings do not imply Australian women favour voluntary over paid work, but instead lack paid work opportunities. Researchers, therefore, need to move from descriptive accounts of volunteers' activities to understanding the varied principles in specific countries that shape divisions of labour.

Not only is there a variation in cultural perceptions of volunteers and professional closure, but differences are also found between sectors in particular societies. In her study of 29 volunteers in Britain, Taylor (2005) found that professionalisation levels differed substantially between healthcare and community work. A study in The Netherlands based on 144 in-depth interviews with professionals and volunteers and observations in 14 care and social support organisations came to similar conclusions (van Bochove et al., 2018). In long-term care organisations, such as nursing homes, the boundaries between volunteers and professionals were clearer than in social support organisations, including community centres. In nursing homes, volunteers were generally excluded from the professional domain of the nurse, given their assumed lack of knowledge, skills, authority and reliability. Against this, the roles of social workers and volunteers largely overlapped, with volunteers perceived as "professionalised" invited to take over care tasks and receive privileges normally reserved for paid staff. It was concluded that differences in exclusionary social 
closure explained these outcomes. In less federalised countries, like the United States, further complexity exists because of variations in health professional closure between states-with resulting implications for relationships with volunteers (Saks, 2015b).

\section{The impact of differences among volunteers}

Nonetheless, the type of professional closure in specific societies cannot explain all variations from a neo-Weberian perspective. Several authors have shown that other mechanisms are involved in the everyday practices of volunteers and professionals.

Differences between volunteers - and how professionals perceive them-appear most important. Merrell (2000), in a qualitative study of two community well-women clinics, and Hoad (2002), in an analysis of 14 community care schemes for older people centred on semi-structured interviews, both underline in their boundary work research the importance of seeing the volunteer workforce as differentiated in social and work backgrounds in interacting with healthcare professionals. Such variation can affect the degree to which volunteers substitute for, or complement, professional and other paid staff. This is accentuated by research that differentiates between long-term and short-term volunteers (Eliasoph, 2011) and corporate and student volunteers (Handy, Mook \& Quarter, 2008). The presence of experienced "professional" volunteers can therefore lead to seemingly peaceful boundary deconstruction even if conflicts are still possible.

Boundary work research projects based on interviews and observations in nursing homes, day care centres and community centres by van Bochove support this interpretation in The Netherlands (van Bochove et al., 2018, Verhoeven \& van Bochove, 2018). Although van Bochove and colleagues (2018) argue that the roles of paid health and social care professionals are more distinctive in nursing homes than community centres, even here boundaries sometimes crossed. The perceived characteristics of volunteers were important, alongside the circumstances under which nurses worked. Possession of a workload requiring experience allowed paid professionals to hand tasks to "professionalised" volunteers-and where "welcoming work" was performed by paid professionals, boundaries were changed. However, these boundaries were not completely diminished, as professionals decided which volunteers should be welcomed and when. Overgaard (2019) therefore rightly notes that the form and content of voluntary work differs across contexts and does not just reflect volunteers' personal preferences. There may also be legal constraints on the tasks volunteers perform from sector to sector in different countries-such that professionals are not the only group impacted by state regulation (Milbourne, 2013).

Different organisational engagements of volunteers in the public and private sectors may greatly influence the nature of the interactions with professionals in healthcare and other fields too. Verhoeven and van Bochove (2018) found different types of volunteers in their study of client care for groups including the elderly and disabled. Like Taylor (2005), they noted that generational, socioeconomic, cultural and health differences shaped volunteer 
priorities and expectations of work. Some volunteers had mild disabilities themselves and wanted to be useful, such as by assisting clients with more severe disabilities, and wanted to belong to a community (Verplanke, 2014). However, professionals argued that such volunteers were "taking more than they can bring" - as they cost them time instead of lightening their workload-and they therefore preferred more "vigorous" volunteers (Verhoeven \& van Bochove, 2018) with motives such as using voluntary work to acquire skills for future paid employment (Verplanke, 2014).

Some volunteers were trained during voluntary work and became more professionalised, or were already professionals in the same or another field of work using their skills in volunteer roles (van Bochove \& Oldenhof, 2020). Hoad (2002) in England and Handy, Mook and Quarter (2008) in Canada noted that, in some organisations, this can occur coterminously. Worryingly, some volunteers may have predatory motives - as illustrated by allegations of humanitarian charity volunteer abuse in the Calais Jungle camp in France (Bulman, 2016), paralleling the rising number of heath professional scandals (Chamberlain, 2015).

\section{The impact of the market situation of volunteers}

The importance of market structures in which volunteers are situated in their relationship with professionals in boundary work also needs to be grasped. Hardill \& Baines (2011) and Muehlebach (2012) in Britain and Italy respectively suggest that volunteers in health and care are used to fill gaps in the retrenching welfare state. In neo-Weberian terms, the practice of labour substitution in the market indicates that volunteer roles are becoming increasingly "work-like" and "responsibilised" (Hardill \& Baines, 2011; Merrell, 2000). Just like paid professionals and other workers, unpaid volunteers have to be recruited, selected and dependable. Ganesh and McAllum (2012) argue that professionalisation is a "colonising logic" reshaping volunteering. According to them, volunteering is associated with feminine values such as emotions and caring, while professional work has more masculine overtones, focused on efficiency and achievement. The professionalisation of voluntary work thus means marketisation and rationalisation, which may lead to more convenience- than needbased service delivery.

The boundaries between volunteers and professionals are therefore becoming more blurred and the challenge has increased because the professionalisation of volunteers might lead to the deprofessionalisation of subordinated professions (Andrews \& Wærness, 2011). However, as van Bochove and Oldenhof (2020) show, such professionalisation can coincide with the facilitating recruitment of paid volunteer coordinators. Such match-making activities between volunteers and professionals is increasingly important.

It is also vital to distinguish the formal activities of volunteers from other responsibilised actors, such as the growing number of clients who engage in self-help (Mik-Meyer, 2017) and the numerous informal family carers across Europe (Verbakel, 2014). This separation has been challenged by Litwak (1985), as we move towards increased welfare mix, 
outsourcing and task shifting. This highlights the complexity of the healthcare division of labour, as professionals working alongside volunteers become more involved in supporting self-sustained and informal care (Smith, 2007).

\section{Non-professionalised healthcare work}

Nonetheless, the interstitial group of waged non-professionalised health support workers, lying between professionals and volunteers, forms the largest and most invisible part of the modern healthcare labour force (Saks, 2020). This is illustrated in Britain where more than one million health support workers outnumber registered professional nurses and doctors combined (Cavendish, 2013). They also occupy a pivotal position in delivery/service integration with a growing ageing population with chronic conditions and limited resources. As such, these workers provide crucial frontline paid healthcare support in private and public settings internationally (Saks, 2020). However, they do not possess professional qualifications and are not directly regulated by statutory professional bodies - even if, like volunteers, there are legislative boundaries to their work (Manthorpe \& Martineau, 2008).

However, although support workers are part of the paid occupational landscape in a competitive market, as the United States illustrates, health support workers are generally low waged and live on part-time and short-term contracts, with limited education and career prospects (Polson, 2013). A similar situation prevails in Canada and Britain, which may partly justify defining such workers as a "precariat" (Zagrodney \& Saks, 2017) - not least as they are seen exploitatively as a cheap labour substitute for more expensive professional personnel (McKee, Dubois \& Sibbald, 2006), and contain disproportionate numbers of minority ethnic and female workers (Saks, 2020). Governments and employers therefore need to assess the balance of risk against savings on expenditure-just as with the work of volunteers in professionalised environments.

One reason for caution in ascribing the homogenous label of "precariat" to health support workers is that they are similarly differentiated to professions and volunteers. This is exemplified by the study of health support worker regulation by Saks and colleagues (2000) for the United Kingdom Departments of Health - based on a literature review, a survey of health and social services chief executives, interviews with key players, focus groups and regional workshops with stakeholders. Over 300 different types of health support workers were found, from healthcare assistants and alternative practitioners to dental nurses and occupational therapy aides. Moreover, their job descriptions were often inconsistent, even within the same category-with further differentiation in organisational employment, ranging from people's own homes to residential establishments and hospitals. This diversification results in many varied links between professionals and volunteers. Indeed, at the top of the health support work hierarchy professionalisation is possible-as recently happened with operating department practitioners (Saks \& Allsop, 2007). 
The significance of such diversification for the relationship between professionals and nonprofessionalised health workers-paralleling the connections between health professionals and volunteers - needs to be understood. Bach, Kessler and Heron (2012) analysed interestbased boundary disputes between nurses and healthcare assistants in Britain. They found that healthcare assistants tended to take over direct patient care, while nurses were responsible for complex administrative tasks. The nurses were ambivalent about this: they did not want to undertake the "dirty work" of healthcare assistants, but recognised their practice fell short of the holistic ideology of the future nurse. Boundary work between medical professionals and non-professionalised health personnel-including alternative medicine practitioners - has also been studied internationally, including in Britain and the United States (Saks, 2015b). Following Merrell (2000), this highlights the need for further research on the relationship between paid non-professionalised healthcare workers and volunteers in the complex division of labour.

\section{Discussion}

The central research question of outlining the characteristics of, and divisions within and between, the various parties in healthcare relevant to the interlinkage of professionals and volunteers has now been addressed. In so doing, this essay has drawn on empirical research in modern neo-liberal societies from a neo-Weberian perspective and the complementary interactionist analysis of boundary work. It is argued that there needs to be greater recognition of the differential occupational environments surrounding professionals and volunteers if their market-based role in delivering services is to be understood. In this respect, a wider and more sophisticated appreciation is required than that between the "catch-all" categories of professionals and volunteers. At the extremes, this includes the interface between medical professionals and untrained volunteers in the division of labour, given the former's leadership and coordination role (Weiss, Tilin \& Morgan, 2013). However, in terms of delivery such relationships have multiple reference points including the client, informal carers, allied and limited health professions, and paid non-professionalised health workers - in addition to differentiated volunteers themselves.

\section{Future directions}

Along with the variable rights and responsibilities of healthcare groups in different sociopolitical and organisational contexts, two types of diversification need to be acknowledged in future research. The first is diversification within groups of professionals and volunteers and associated co-working. The second is diversification from adding more actors into the healthcare division of labour-going beyond simplistic professional-volunteer relationships to consider their interface with non-professionalised health workers, clients and carers. This requires greater understanding of dyads, triads, and larger groups, involving relationships based on different levels of expertise linked to experience and/or certificated knowledge (Bertucci et al., 2010). Such research into the impact of diversification and boundary work is 
crucial to both our academic understanding and more informed healthcare policy, as well as meso- and micro-level decision making.

\section{Policy recommendations}

Progressing public and private sector policy and practical decision making is particularly important where more extensive multi-dimensional collaboration in healthcare is required in fast-changing environments. Defining best practice for collaboration between professionals and volunteers in light of further research is key to minimising risk and maximising benefit to clients and the wider public (Chamberlain, Dent \& Saks,2018). The research considered in this article has already highlighted that more attention should be given to the occupational and organisational context of work and the characteristics of volunteers in deciding the optimum skill mix. This should go beyond using volunteers to fill gaps, to more extensively employing their skills in synergy with professionals and other paid workers. From a boundary perspective, a pragmatic balance is needed between encouraging others to join their domain and demarcation work emphasising differences in knowledge, authority and reliability (van Bochove et al., 2018).

\section{Limitations}

One limitation of this essay is the literature review based on combining earlier research findings of the authors with selective updated literature searches. A more systematic literature review would increase its rigour. Future research would also be enhanced by increasing sensitivity to the histories and cultures of national socio-political contexts in modern societies using comparative methods (Burau, 2019). Further work here could also be undertaken on professionals and volunteers in under-researched countries, such as Poland (Krakowiak \& Pawłowski, 2018). These, though, are agendas for researchers building on this necessarily short essay.

\section{Conclusion}

Specific international contexts therefore need to be considered in more detail as they impact on future healthcare policy prospects - in terms, for instance, of acceptable risks and responsibilities for professionals and volunteers (Overgaard, 2015). This essay argues researchers should study the relationship between professionals and volunteers further in modern societies from a neo-Weberian and complementary boundary work perspective-albeit with a neo-institutionalist focus on competing institutional forms, from state and public sector organisations to private corporations and citizens themselves (Saks, 2016). This macro context, alongside more micro- and meso- analyses of professionals and volunteers, will improve understanding of the interface between them. Central to this agenda is recognition of a diverse healthcare division of labour, which acknowledges that professionals and volunteers are not the only players in the game, nor are they clearlydefined and cohesive groups. Such more refined theoretical and empirical research will 
promote further policy and practice enhancements serving clients and the wider public interest (Chamberlain, Dent \& Saks, 2018).

\section{Article history}

Received: 24 Aug 2020

Accepted: 17 Mar 2021

Published: 25 May 2021

\section{References}

Andrews, T. M., \& Wærness, K. (2011). Deprofessionalization of a female occupation: Challenges for the sociology of professions. Current Sociology, 59(1), 42-58. https://doi.org/10.1177/0011392110385969

Bach, S., Kessler, I., \& Heron, P. (2012). Nursing a grievance? The role of healthcare assistants in a modernized national health service. Gender, Work and Organization, 19(2), 205-224. https://doi.org/10.1111/j.1468-0432.2009.00502.x

Bertucci, A., Conte, S., Johnson, D. W., \& Johnson, R. T. (2010). The impact of size of cooperative group on achievement, social support and self-esteem. Journal of General Psychology, 137(2), 256-272. https://doi.org/10.1080/00221309.2010.484448

Borsay, A., \& Hunter, B. (Eds.) (2012). Nursing and midwifery in Britain since 1700. Basingstoke: Palgrave Macmillan. https://doi.org/10.1007/978-1-137-02421-3

Bulman, M. (2016). Calais Jungle volunteers accused of "sexually exploiting" camp's refugees. Retrieved from

https://www.independent.co.uk/news/world/europe/calais-jungle-volunteers-sexrefugees-allegations-facebook-care4calais-a7312066.html

Burau, V. (2019). Comparative health research. In M. Saks \& J. Allsop (Eds.) Researching health: Qualitative, quantitative and mixed methods (p. 453-471). London: Sage.

Carvalho, T. (2014). Changing connections between professionalism and managerialism: A case study of nursing in Portugal. Journal of Professions and Organization, 1(2): 176190. https://doi.org/10.1093/jpo/jou004

Cavendish, C. (2013). The Cavendish Review: An independent review into healthcare assistants and support workers in the NHS and social care settings. London: Department of Health.

Chamberlain, J. M. (2015). Medical regulation, fitness to practise and revalidation. Bristol: Policy Press.

Chamberlain, J. M., Dent, M., \& Saks, M. (Eds.). (2018). Professional health regulation in the public interest: International perspectives. Bristol: Policy Press. https://doi.org/10.1332/policypress/9781447332268.001.0001

Claxton-Oldfield, S., Gibbon, L., \& Schmidt-Chamberlain, K. (2011). When to say 'Yes' and when to say 'No': Boundary issues for hospice palliative care volunteers. American Journal of Hospice and Palliative Medicine, 28 (6), 429-434. https://doi.org/10.1177/1049909110397926 
de Bont, A. A., van Exel, N. J. A., Coretti, S., Guldem Okem, Z., Janssen, M., Lofthus Hope, K., ... \& Wallenburg, I. (2016). Reconfiguring health workforce: A case-based comparative study explaining the increasingly diverse professional roles in Europe. BMC Health Services Research, 16(1), 637. https://doi.org/10.1186/s12913-016-1898-0

Eliasoph, N. (2011). Making volunteers: Civic life after welfare's end. Princeton, NJ: Princeton University Press. https://doi.org/10.23943/princeton/9780691147093.001.0001

Fournier, V. (2000). Boundary work and the (un)making of the professions. In N. Malin (Ed.). Professionalism, boundaries and the workplace (pp. 67-86). London: Routledge.

Freidson, E. (2001). Professionalism: The third logic. Cambridge: Policy Press.

Ganesh, S., \& McAllum, K. (2012). Volunteering and professionalization. Management Communication Quarterly, 26(1), 152-158. https://doi.org/10.1177/0893318911423762

Gieryn, T. F. (1995). Boundaries of science. In S. Jasanoff, G. E. Markle, J. C. Petersen \& T. Pinch (Eds.) Handbook of science and technology studies (p. 393-443). London: Sage.

Halffman, W. (2003) Boundaries of regulatory science (Doctoral dissertation). Amsterdam: University of Amsterdam.

Hallett, R. E., \& Barber, K. (2014). Ethnographic research in a cyber era. Journal of Contemporary Ethnography, 43(3), 306-330. https://doi.org/10.1177/0891241613497749

Handy, F., Mook, L., \& Quarter, J. (2008). The interchangeability of paid staff and volunteers in nonprofit organizations. Nonprofit and Voluntary Sector Quarterly, 37(1), 76-92. https://doi.org/10.1177/0899764007303528

Handy, F., \& Srinivasan, N. (2004). The demand for volunteer labor: A study of hospital volunteers. Nonprofit and Voluntary Sector Quarterly, 34(4), 491-509. https://doi.org/10.1177/0899764005278037

Hardill, I., \& S. Baines, S. (2011). Enterprising care? Unpaid voluntary action in the 21st century. Bristol: Policy Press. https://doi.org/10.1332/policypress/9781847427212.001.0001

Hoad, P. (2002). Drawing the line: The boundaries of volunteering in the community care of older people. Health and Social Care in the Community, 10(4), 239-246. https://doi.org/10.1046/.1.1365-2524.2002.00361.x

Johnson, T. (2016). Professions and power. Abingdon: Routledge Revivals. https://doi.org/10.4324/9781315471372

King, O., Nancarrow, S., Grace, S., \& Borthwick, A. (2019). Interprofessional role boundaries in diabetes education in Australia. Health Sociology Review, 28(2), 162-176. https://doi.org/10.1080/14461242.2019.1600380

Krakowiak, P., \& Pawłowski, L. (2018). Volunteering in hospice and palliative care in Poland and Eastern Europe. In R. Scott, \& S. Howlett (Eds.). The changing face of volunteering in hospice and palliative care (p. 83-95). Oxford: Oxford University Press. https://doi.org/10.1093/oso/9780198788270.003.0007

Kreutzer, K., \& Jäger, U. (2011). Volunteering versus managerialism: Conflict over organizational identity in voluntary associations. Nonprofit and Voluntary Sector Quarterly, 40(4), 634-661.https://doi.org/10.1177/0899764010369386 
Litwak, E. (1985). Helping the elderly: The complementary roles of informal networks and formal systems. New York: Guilford Press.

McKee, M., Dubois, C-A., \& Sibbald, B. (2006). Changing professional boundaries. In C-A. Dubois, M. McKee, \& E. Nolte (Eds.) Human resources for health in Europe (p. 63-78). Maidenhead: Open University Press.

Manthorpe, J., \& Martineau, S. (2008). Support workers: Their role and tasks: A scoping review. London: King's College.

Merrell, J. (2000). Ambiguity: Exploring the complexity of roles and boundaries when working with volunteers in well woman clinics. Social Science and Medicine, 51(1), 93-102. https://doi.org/10.1016/S0277-9536(99)00442-6

Mik-Meyer, N. (2017). The power of citizens and professionals in welfare encounters. Manchester: Manchester University Press. https://doi.org/10.7765/9781526110305

Milbourne, L. (2013). Voluntary sector in transition: Hard times or new opportunities? Bristol: Policy Press. https://doi.org/10.1332/policypress/9781847427236.001.0001

Muehlebach, A. (2012). The moral neoliberal: Citizenship and welfare in Italy. Chicago, IL: University of Chicago Press. https://doi.org/10.7208/chicago/9780226545417.001.0001

Nancarrow, S. (2020). The interface of health support workers with the allied health professions. In M. Saks (Ed.), Support workers and health professions in international perspective: The invisible providers of healthcare. Bristol: Policy Press. https://doi.org/10.2307/j.ctv1453kz6.10

Nixon, S., \& Crewe, B. (2004). Pleasure at work? Gender, consumption and work-based identities in the creative industries. Consumption Markets and Culture, 7(2), 129147. https://doi.org/10.1080/1025386042000246197

Noordegraaf, M. (2016). Reconfiguring professional work: Changing forms of professionalism in public services. Administration and Society, 48(7), 783-810. https://doi.org/10.1177/0095399713509242

Overgaard, C. (2015). The boundaries of care work: A comparative study of professionals and volunteers in Denmark and Australia. Health and Social Care in the Community, 23(4), 380-388. https://doi.org/10.1111/hsc.12154

Overgaard C. (2019). Rethinking volunteering as a form of unpaid work. Nonprofit and Voluntary Sector Quarterly, 48 (1), 128-145. https://doi.org/10.1177/0899764018809419

Parkin, F. (1979). Marxism and class theory: A bourgeois critique. London: Tavistock.

Parry, N., \& Parry, J. (1976). The rise of the medical profession. London: Croom Helm.

Polson, D. (2013). The caring precariat: Home healthcare work in New York City (Doctoral dissertation). New York: City University.

Saks, M. (2012). Defining a profession: The role of knowledge and expertise. Professions and Professionalism, 2(1), 1-10. https://doi.org/10.7577/pp.v2i1.151 
Saks, M. (2015a). Health policy and complementary and alternative medicine. In E. Kuhlmann, R. Blank, I. Bourgeault \& C. Wendt. (Eds.) The Palgrave International Handbook of Healthcare Policy and Governance (p. 494-509). Basingstoke: Palgrave Macmillan. https://doi.org/10.1057/9781137384935 30

Saks, M. (2015b). The professions, state and the market: Medicine in Britain, the United States and Russia. Abingdon: Routledge. https://doi.org/10.4324/9781315727493

Saks, M. (2016). Review of theories of professions, organizations and society: NeoWeberianism, neo-institutionalism and eclecticism. Journal of Professions and Organization, 3(2): 170-187. https://doi.org/10.1093/jpo/jow005

Saks, M. (2020). Introduction: Support workers and the health professions. In M. Saks (Ed.), Support workers and the health professions in international perspective: The invisible providers of healthcare (p. 1-14). Bristol: Policy Press. https://doi.org/10.46692/9781447352112

Saks, M. (2021). Professions: A key idea for business and society. Abingdon: Routledge. https://doi.org/10.4324/9780429465802

Saks, M., \& Allsop, J. (2007). Social policy, professional regulation and health support work in the United Kingdom. Social Policy and Society, 6(2): 165-177. https://doi.org/10.1017/S1474746406003435

Saks, M., Allsop, J., Chevannes, M., Clark, M., Fagan, R., Genders, N., ... Unell, J. (2000). Review of Health Support Workers. Leicester: UK Departments of Health/De Montfort University.

Smith, G. (2007). Families, carers and professionals: Building constructive conversations. Chichester: John Wiley \& Sons.

Stevens, R. (2003). Medical practice in modern England: The impact of specialization and state medicine. Piscataway, NJ: Transaction Publishers.

Taylor, R. (2005). Rethinking voluntary work. Sociological Review, 52(2), 117-135. https://doi.org/10.1111/j.1467-954X.2005.00576.x

Turner, B. (1995). Medical power and social knowledge. London: Sage.

van Bochove, M., \& Oldenhof, L. (2020). Institutional work in changing public service organizations: The interplay between professionalization strategies of non-elite actors. Administration and Society, 52(1), 111-137. https://doi.org/10.1177/0095399718786880

van Bochove, M., Tonkens, E., Verplanke, L., \& Roggeveen, S. (2018). Reconstructing the professional domain: Boundary work of professionals and volunteers in the context of social service reform. Current Sociology, 66(3), 392-411. https://doi.org/10.1177/0011392116677300

Verbakel, E. (2014). Informal caregiving and well-being in Europe: What can ease the negative consequences for caregivers? Journal of European Social Policy, 24(5), 424441. https://doi.org/10.1177/0958928714543902

Verhoeven, I., \& van Bochove M. (2018). Moving away, toward, and against: How front-line workers cope with substitution by volunteers in Dutch care and welfare services. Journal of Social Policy, 47(4), 783-801. https://doi.org/10.1017/S0047279418000119 
Verplanke, L. (2014). Gratis maar niet voor niks: Motieven van vrijwilligers in zorg en welzijn [Unpaid but not for free: Motives of volunteers in health and social care]. In M. van Bochove, E. Tonkens, \& L. Verplanke (Eds.) (2014). Kunnen we dat (niet) aan vrijwilligers overlaten? Nieuwe verhoudingen tussen vrijwilligers en professionals in zorg en welzijn [Can't we leave that to the volunteers? New relationships between volunteers and professionals in health and social care]. The Hague: Platform31.

Weiss, D., Tilin, F., \& Morgan, M. (2013). The interprofessional healthcare team: Leadership and development. Burlington, MA: Jones and Bartlett.

Wilson, J. (2012). Volunteerism research: A review essay. Nonprofit and Voluntary Sector Quarterly, 41(2), 176-212. https://doi.org/10.1177/0899764011434558

Zagrodney, K., \& Saks, M. (2017). Personal support workers in Canada: The new precariat? Healthcare Policy, 13(2), 31-39. https://doi.org/10.12927/hcpol.2017.25324 